\title{
RETAIL INVESTORS AWARENESS TOWARDS EQUITY INVESTMENT - WITH REFERENCE TO BHOPAL CITY
}

\author{
Sakshi Agrawal \\ Executive Director, Development, the SAGE Group Bhopal, \\ SIRT College, Bhopal, India \\ Dr. Simrina Singh \\ Professor, Department of Management, \\ SIRTS College, Bhopal, India
}

\begin{abstract}
An Economy progresses further when its citizens in any capacity add to the capital formation in terms of savings and investments. This is done with the help of mutual fund investors or through the retail investors. The retail Investors in India are very few as compared to the other investors who are investing through other financial services. This paper works on the behavior pattern of the retail investors with special reference to Bhopal. The investment by these investors at time is overshadowed by the level of understanding they have about financial securities and their experiences with the stock market. The retail investors have some apprehensions regarding the working of stock market and the feeling lurks in their mind, that whatever theory says, the stock market may not work as per the fundamental analysis or even on the basis of technical analysis, which though is very explicit, yet may not reflect the true picture. The general perception by the retail investors is the market works on random events or there are certain stock giants who make the market. Keeping this in mind the research is conducted by taking into consideration five factors, which include retail investors' predictive skills, purchase price of the stock as a reference point for trading, experiences with National Stock Exchange, preference of short term investment and sticking on to looser stock and selling the winners. The study supports the given factors which reflect the behavior of these investors.
\end{abstract}

Key word: Retail Investors, Financial Securities, Predictive Skills, Short Term Investment.

Cite this Article: Sakshi Agrawal and Dr. Simrina Singh, Retail Investors Awareness Towards Equity Investment - With Reference to Bhopal City, International Journal of Management, 10 (3), 2019, pp. 8-14.

http://iaeme.com/Home/issue/IJM?Volume=10\&Issue $=3$ 


\section{INTRODUCTION}

An Economy of a country progresses when its savings are mobilized in the form of investments and the leakages of the consumption pattern changes in giving an injection to the Economy. As per the economic thought savings are leakages from the consumption pattern and all investments are injections in enhancing capital formation of an economy. There are avenues open to the retail investors where they can realize their savings in getting better returns.

Stock markets are the public market where the trading of the equities, stock derivatives and other financial products are traded. The basic reason of this part of Financial Market is that it provides liquidity to the investors. The different investors who have been a part of this market are those who trade either in Secondary market and those who trade in Primary market. There is discretion of this market and that being the Money Market and Capital Market, characterized on the basis of time duration of investments, where the former deals with the investments of less than one year and the latter with more than one year. The Mutual Funds are gearing up with the investment stocks and they have different plans suiting the investors demand or requirements. They have absorbed lot many retail investors within their fold, yet there are still Investors who work on their own and have trust in their capability and are a part of the stock market. They are called the Retail investors.

Retail Investors can be passive, active or both. Active retail investors Invest in the Primary Market as well as in Secondary Market through direct participation. On the other hand passive investors do not invest in securities giving them quick returns. The SEBI directs the investors to have a demat account and for that PAN Number is required. This account is linked to National Securities Depository Limited and Central Depository Services (India) Limited. The Investor accounts with these two depositories as of 31 July 2017 stands at 28,975,484 (CDSL 12,951,660 + NSDL 16,023,824) or 29 million out of 1.33 billion population

\section{NEED FOR THE STUDY}

With the massive growth of mutual funds and other financial products, it has been observed that the number of retail investors is comparatively low. This may be due to many factors, which may include demographic changes, change in the financial markets, economic factors and even political factors. The study attempts to understand the factors which affect the retail investors who are investing in equity market. The knowledge of their predictive skills and other factors are looked into, by keeping in mind Bhopal city.

\section{LITERATURE REVIEW}

The various research papers were studied and to cite a few- as per Dr. Makarand S. Wazal and Sharma Sudesh in their paper titled "Participation of Retail Investors in Indian Equity" have estimated that the retail Investors in India are estimated to be $4.45 \%$ of the total Indian Population and if compared with the world India comes among the lowest country having less number of retail investors. As per the paper the $50 \%$ of the Retail Investors are skewed towards the western Zone of India.

Pinto Praksh \& Munshi MM in their paper "An Analysis of Selection Behaviour of Retail Investors towards Mutual Funds : A Study With Reference to Udupi District Karnataka" state that the general retailers in India would prefer to go for very safe investments. This may be due to their risk adversity factor, and their investment in the security market may also be determined by the type of knowledge they have.

Mark K Y Mak in his paper "An Exploratory Study of Investment Behaviour of Investors" explains that the financial product providers are able to predict the marketability of their product as in the study it has been concluded that the demographic, sociological and psychological 
factors influence the choice of investments made by the investors. The planning and launch of the product is an outcome of the factor analysis.

\section{OBJECTIVES OF THE STUDY}

The objective of the study was to analyze the factors dominating the retail investors in the equity market which include use of predictive skills to outperform the market, purchase price of stocks as a reference point in trading, trading on National Stock Exchange is usually determined by past experiences in the market, preferences of short term investment and holding onto looser stocks and selling winners.

\section{RESEARCH METHODOLOGY}

The study conducted is based on primary data analysis, and further analysis was done. The details are as follows:

\subsection{Data Collection}

Primary data has been collected through questionnaire method.

\subsection{Sample Size}

The Investors of Bhopal with an approximate population being 40000 a sample size of 500 investors were taken. The questionnaire was floated in the investors market through hard copy as well as soft copy. The stock market behavior was on a Likert scale ranging from strongly disagrees, disagrees, not sure, agrees, strongly agrees.

\subsection{Test Administered}

a. KMO measure of Sampling Adequacy test was administered and Cronbach's Alpha Test to measure the reliability and validity of the test.

b. Chi Square Test is administered to know the statistical significance of the study for the primary data.

c. All the test are administered by taking alpha value of 0.05 and confidence level of $95 \%$ with 4.36 confidence interval.

\subsection{Research Design}

The study is descriptive and exploratory in design, where survey method was used for data collection. Data is gathered from the investors of Bhopal region. The study undertakes Random Sampling.

\section{Data Presentation \& Interpretation}

The questionnaire prepared for the objective of the paper had the following factors where answers were taken on five point likert scale viz strongly disagree, disagree, not sure, agree, strongly agree. The factors were

- I always use predictive skills to outperform the market.

- I usually base on the purchase price of stocks as a reference point in trading

- My trading on NSE is usually determined by past experiences in the market.

- I often have preference of short term investment.

- I always prefer holding onto looser stocks and selling winners. 
With the Cronbach's alpha tested at .773, the analysis was done further and the hypothesis formulated is tested with Chi square test.

For the above factors for which data has been taken relevant hypothesis is made and are accordingly tested.

\subsubsection{Use Predictive Skills to Outperform the Market}

$\mathrm{H}_{01}$ : There is no significant difference between predictive skill of investor and stock market investor behaviour.

$\mathrm{H}_{\mathrm{a} 1}$ : There is a significant difference between predictive skill of investor and stock market investor behaviour.

Table 1: Use Predictive Skill to Outperform the Market

\begin{tabular}{|c|c|c|c|c|c|c|c|c|c|c|}
\hline Factor & $\begin{array}{c}\text { Strongly } \\
\text { Disagree }\end{array}$ & $\%$ & Disagree & $\%$ & $\begin{array}{c}\text { Not } \\
\text { Sur } \\
\text { e }\end{array}$ & \% & $\begin{array}{c}\text { Agre } \\
\text { e }\end{array}$ & $\begin{array}{c}\text { Strong } \\
\text { ly } \\
\text { Agree }\end{array}$ & $\mathbf{\%}$ \\
\hline 1 & 188 & 37.6 & 90 & 18.0 & 87 & 17.4 & 106 & 21.2 & 29 & 5.8 \\
\hline
\end{tabular}

Table 2 Use Predictive Skill to Outperform the Market

\begin{tabular}{|c|c|}
\hline Chi-Square & 122.000 \\
\hline Df & 4 \\
\hline Asymp. Sig. & .000 \\
\hline
\end{tabular}

The test statistics of chi test is statistically significant as the chi(4) p value is $0.000<0.05$, hence $\mathrm{H}_{1}$ is not rejected and the $\mathrm{H}_{0}$ is rejected. As per the given conditions, there is a significant difference between variable predictive skill of investor and stock market investor behaviour.

\subsubsection{Base the Purchase Price of Stocks as Reference Point in Trading}

$\mathrm{H}_{02}$ : There is no significant difference between stock purchase price as reference point and stock market investor behaviour.

$\mathrm{H}_{\mathrm{a} .2}$ : There is a significant difference between stock purchase price as reference point and stock market investor behaviour.

Table 3 Base the Purchase Price of Stocks as Reference Point in Trading

\begin{tabular}{|c|c|c|c|c|c|c|c|c|c|c|}
\hline Factor & $\begin{array}{c}\text { Strongly } \\
\text { Disagree }\end{array}$ & \% & Disagree & $\mathbf{\%}$ & $\begin{array}{c}\text { Not } \\
\text { Sure }\end{array}$ & $\mathbf{\%}$ & Agree & $\%$ & $\begin{array}{c}\text { Strongly } \\
\text { Agree }\end{array}$ & $\%$ \\
\hline 2. & 188 & 37.6 & 90 & 18.0 & 87 & 17.4 & 106 & 21.2 & 29 & 5.8 \\
\hline
\end{tabular}

Table 3 Base the Purchase Price of Stocks as Reference Point in Trading

\begin{tabular}{|c|c|}
\hline Chi-Square & $92.480^{\mathrm{a}}$ \\
\hline Df & 4 \\
\hline Asymp. Sig. & .000 \\
\hline
\end{tabular}

The test statistics of chi test is statistically significant as the chi(4) $p$ value is $0.000<0.05$, hence $\mathrm{H}_{1}$ is not rejected and the $\mathrm{H}_{0}$ is rejected. It means that there is a significant difference between variable stock purchase price as reference point and stock market investor behaviour.

\subsubsection{Trading on NSE is usually determined by past experiences in the market.}

$\mathrm{H}_{03}$ : There is no significant difference between the variable, past experience of trading on NSE and stock market investor behaviour.

$\mathrm{H}_{\mathrm{a} 3}$ : There is a significant difference between the variable, past experience of trading on NSE and stock market investor behaviour. 
Table 4 Trading on NSE is usually determined by past experiences in the market

\begin{tabular}{|c|c|c|c|c|c|c|c|c|c|c|}
\hline Factor & $\begin{array}{c}\text { Strongly } \\
\text { Disagree }\end{array}$ & $\mathbf{\%}$ & Disagree & $\mathbf{\%}$ & $\begin{array}{c}\text { Not } \\
\text { Sure }\end{array}$ & $\mathbf{\%}$ & Agree & $\mathbf{\%}$ & $\begin{array}{c}\text { Strongl } \\
\text { y agree }\end{array}$ & $\mathbf{\%}$ \\
\hline 3 & 11 & 2.2 & 40 & 8.0 & 75 & 15.0 & 295 & 59.0 & 79 & 15.8 \\
\hline
\end{tabular}

Table 5 Past Experience of Trading on NSE

\begin{tabular}{|c|c|}
\hline Chi-Square & $158.720^{\mathrm{a}}$ \\
\hline Df & 4 \\
\hline Asymp. Sig. & .000 \\
\hline
\end{tabular}

The test statistics of chi test is statistically significant as the chi(4) $p$ value is $0.000<0.05$, hence $\mathrm{H}_{1}$ is not rejected and the $\mathrm{H}_{0}$ is rejected. As per the given conditions, there is a significant difference between the variable past experience of trading on NSE and stock market investor behaviour.

\subsubsection{Preference of short term investment}

$\mathrm{H}_{04}$ : There is no significant difference between the variable, preference of short term investment and stock market investor behaviour.

$\mathrm{H}_{\mathrm{a} .4}$ : There is a significant difference between the variable, preference of short term investment and stock market investor behaviour.

Table 6 Preference of short term investment

\begin{tabular}{|c|c|c|c|c|c|c|c|c|c|c|}
\hline Factor & $\begin{array}{c}\text { Strongly } \\
\text { Disagree }\end{array}$ & $\mathbf{\%}$ & Disagree & $\mathbf{\%}$ & $\begin{array}{c}\text { Not } \\
\text { Sur } \\
\text { e }\end{array}$ & $\mathbf{\%}$ & Agree & $\%$ & $\begin{array}{c}\text { Stron } \\
\text { gly } \\
\text { Agre } \\
\text { e }\end{array}$ & $\%$ \\
\hline & 145 & 29.0 & 118 & 23.6 & 90 & 18.0 & 130 & 26.0 & 17 & 3.4 \\
\hline
\end{tabular}

Table 7 Preference of Short Term Investment

\begin{tabular}{|c|c|}
\hline Chi-Square & $40.240^{\mathrm{a}}$ \\
\hline Df & 4 \\
\hline Asymp. Sig. & .000 \\
\hline
\end{tabular}

The test statistics of chi test is statistically significant as the chi(4) p value is $0.000<0.05$, hence $\mathrm{H}_{1}$ is not rejected and the $\mathrm{H}_{0}$ is rejected. As per the given conditions, there is a significant difference between the variable preference of short term investment and stock market investor behaviour.

\subsubsection{Prefer Holding on Looser Stocks and Selling Winners}

$\mathrm{H}_{05}$ : There is no significant difference between the variable, preference to hold looser stock/selling winners and stock market investor behaviour.

$\mathrm{H}_{\mathrm{a}}$ : There is a significant difference between the variable, preference to hold looser stock/selling winners and stock market investor behaviour.

Table 8 Prefer Holding on Looser Stocks and Selling Winners

\begin{tabular}{|c|c|c|c|c|c|c|c|c|c|c|}
\hline Factor & $\begin{array}{c}\text { Strongly } \\
\text { Disagree }\end{array}$ & $\mathbf{\%}$ & Disagree & $\mathbf{\%}$ & $\begin{array}{c}\text { Not } \\
\text { Sure }\end{array}$ & $\mathbf{\%}$ & Agree & $\mathbf{\%}$ & $\begin{array}{c}\text { Stron } \\
\text { gly } \\
\text { Agree }\end{array}$ & $\mathbf{\%}$ \\
\hline 5. & 196 & 39.2 & 115 & 23.0 & 50 & 10.0 & 116 & 23.2 & 23 & 4.6 \\
\hline
\end{tabular}


Table 9 Preference of Short-Term Investment

\begin{tabular}{|c|c|}
\hline Chi-Square & $100.960^{\mathrm{a}}$ \\
\hline Df & 4 \\
\hline Asymp. Sig. & .000 \\
\hline
\end{tabular}

The test statistics of chi test is statistically significant as the chi(4) $p$ value is $0.000<0.05$, hence $\mathrm{H}_{1}$ is not rejected and the $\mathrm{H}_{0}$ is rejected. It means that there is significant difference between the variable preference to hold looser stock/selling winners and stock market investor behavior.

\section{FINDINGS REGARDING STOCK MARKET INVESTOR BEHAVIOR}

- In stock market investor behavior, it is statistically proven that investors use their predictive skills to outperform the market and 59.8\% investors agree to it.

- The research finds that investors take purchase price of stocks as a reference point in trading and $21.2 \%$ of investors agree to the same.

- It is statistically proven that investors' trading on NSE on the basis of past experiences in the market, which helps them to take appropriate decision and 59\% agreed.

- In stock market investor behavior, it is statistically proven that investors prefer to invest on a short term horizon and $26 \%$ investors agree to it.

- The study reveals that investors prefer holding onto looser stocks and selling winners, $23.2 \%$ investors agreed.

\section{CONCLUSION}

The behavior of the retail investors are guided by their predictive skills, purchase price of stocks as a reference point and having confidence on past trading. The investors prefer to invest in short term horizon and they do have the acumen to hold on the looser stocks and to sell the stocks which are volatile or have high velocity transactions. It may further be suggested that with some add on facility on financial literacy, the number of retail investors may increase more resulting in a more vibrant investors and robust stock market.

\section{REFERENCES}

[1] Shaikh AR, Kalkundarikar AB, Analysis of Retail Investor's Behavior in Belgaum District, Karnataka State. Int J Manag Res 1, 2011, pp 22-39.

[2] Brahmabhatt, Kumari PSR, Malekar S, A Study of Investor Behavior on Investment Avenues in Mumbai Fenil. J Marketing Manag Res 1, 2012, pp 49-71.

[3] Barberis N, Shleifer A, Vishny R, A model of investor sentiment. J Financ Econ 49, 1998, pp 307-345.

[4] Sindhu.K.P and Dr. S.Rajitha Kumar, Influence of Characteristics of Mutual Funds on Investment Decisions -A Study, International Journal of Management (IJM), Volume 4, Issue 5, September - October (2013)

[5] Byrne A, Employee saving and investment decisions in defined contribution pension plans: Survey evidence from the UK. Financial Services Review 16, 2007, pp 19-40.

[6] Aruna P, Rajashekar H (2016) Factors influencing investment decisions of retail investorsA descriptive study. International Journal of Business and Management Invention 5, 2016, pp 06-09. 
[7] Vankatachalam G, Prabakaran G, A Study on investors' behavior towards gold exchange traded funds in Indian stock market with special reference to Tamil Nadu, 2015

[8] Dhanaiah G, Prasad RSR, Acharya Nagarjuna Retail Investors' Perception in Financial Markets: A Literature Review and Synthesis. Elk Asia Pacific Journals - Special Issue, 2015

[9] Sindhu. K.P., Dr. Kalidas. M. G. and Anil Chandran. S, A Study on Factors Influencing Investor Sentiment in Indian Stock Market, International Journal of Management (IJM), Volume 5, Issue 1, January (2014)

[10] Gupta LC, Share Holders Survey: Geographic Distribution. Manas Publications, New Delhi, 2014, p: 86

[11] Kothari H, Investors behavior towards investment avenues. Altius Shodh Journal of commerce and management, 2015 